\title{
Monitoring post mortem changes in porcine muscle through 2-D DIGE proteome analysis of Longissimus muscle exudate
}

\author{
Alessio Di Luca', Giuliano Elia², Anne Maria Mullen and Ruth M Hamill ${ }^{1 *}$
}

\begin{abstract}
Background: Meat quality is a complex trait influenced by a range of factors with post mortem biochemical processes highly influential in defining ultimate quality. High resolution two-dimensional Dlfference Gel Electrophoresis (2-D DIGE) and Western blot were applied to study the influence of post mortem meat ageing on the proteome of pork muscle. Exudate collected from the muscle following centrifugation was analysed at three timepoints representing a seven day meat ageing period.

Results: The intensity of 136 spots varied significantly $(p<0.05)$ across this post mortem period and 40 spots were identified using mass spectrometry. The main functional categories represented were metabolic proteins, stress-related proteins, transport and structural proteins. Metabolic and structural proteins were generally observed to increase in abundance post mortem and many likely represent the accumulation of the degradation products of proteolytic enzyme activity. In contrast, stress-related proteins broadly decreased in abundance across the ageing period. Stress response proteins have protective roles in maintaining cellular integrity and a decline in their abundance over time may correlate with a reduction in cellular integrity and the onset of meat ageing. Since cellular conditions alter with muscle ageing, changes in solubility may also contribute to observed abundance profiles.
\end{abstract}

Conclusions: Muscle exudate provided valuable information about the pathways and processes underlying the post mortem ageing period, highlighting the importance of post mortem modification of proteins and their interaction for the development of meat quality traits.

Keywords: 2-D DIGE, Western blot, Exudate, Meat ageing

\section{Background}

Meat quality is a complex trait, influenced by many factors including genetics, nutrition, animal handling, pre and post slaughter handling, processing, and their interactions $[1,2]$. The conversion of muscle to meat occurs via a progression of biochemical events during post mortem ageing [3,4]. During this meat ageing period, key meat quality traits such as colour, tenderness, flavour and water holding capacity (WHC) are developed and improve [4-6].

Several molecular mechanisms have been linked to the conversion of muscle to meat. For example, the calpain proteolytic system has long been considered central to

\footnotetext{
* Correspondence: ruth.hamill@teagasc.ie

${ }^{1}$ Teagasc Food Research Centre, Ashtown, Dublin 15, Ireland

Full list of author information is available at the end of the article
}

post mortem tenderisation [7] and more recently is also thought to influence water-holding capacity [8]. Specifically, it has been observed that calpain plays a central role in proteolysis of certain cytoskeletal proteins (e.g. integrin, desmin) during ageing, improves WHC [8-10] and, by influencing the surface reflectance, pork colour [11]. Additional mechanisms, such as apoptosis, have also been proposed to influence quality [4] and in beef, heat shock protein transcript abundance is specifically associated with impaired tenderness after ageing [12]. However, despite progress in understanding the biochemical events which occur in muscle after death, the processes defining meat quality development have not been fully elucidated [13] and proteomics has great potential to enhance our understanding in this regard [14-16]. The identification of proteins affected by the biochemical processes which occur during meat ageing in a homogenous 
group of animals would contribute to a deeper understanding of the phenomenon [13]. Furthermore, if specific proteins or peptides are identified that are associated with aged meat, these have potential to be applied by industry as indicators of quality. 1-D proteomic analysis has shown that muscle exudate is a rich and reproducible source of muscle proteins, including some myofibrillar proteins [17] and hence has potential as an accessible source of proteins and peptides associated with meat quality.

2-D PAGE is a classical method in proteomics to separate mixtures of proteins in two dimensions $[18,19]$ that has been applied to probe the pathways and processes which underpin quality [20,21], however it has some limitations. In recent years, the method has been refined, introducing fluorescent protein detection (2-D Difference Gel Electrophoresis DIGE) which offers improved sensitivity, more limited experimental variation and ensures accurate within-gel matching [22-24]. 2-D DIGE has not previously been applied to monitor pork meat ageing and its application to muscle exudate offers a novel opportunity to explore the processes underpinning the development of quality and identify specific markers which may have downstream applications for industry. In this study therefore, we aim to identify the post mortem changes in the M. longissimus thoracis et lumborum (LTL) muscle exudate proteome over seven days ageing using 2-D DIGE, mass spectrometry and Western blot.

\section{Results}

\section{Phenotypic data}

Four animals showing uniformity in important meat quality characteristics at days 0 and 1 post mortem (i.e. $\mathrm{pH}_{45}$, $\mathrm{pH}_{\mathrm{u}}$, drip loss and colour) were selected for downstream proteomic analyses. Their meat quality characteristics measured at three timepoints in the ageing period (day 1 , 3 and 7 plus $\mathrm{pH}$ at 45 minutes post mortem) are presented in Table 1 . While shear force did not differ between day 1 and 3 , it declined from $\sim 46$ to $\sim 32$ Newtons $(P=0.002)$ between day 1 and day 7. Cook loss was less on day 7 compared with day $1(P=0.05)$ and the CIE $b^{*}$ (yellowness) colour parameter increased from day 3 to day 7 post mortem $(P=0.02)$.

\section{Identification of differentially expressed spots using 2-D DIGE}

A total of 376 distinct protein spots were detected using Progenesis SameSpots. Differential protein abundance was observed across three timepoints (days 1, 3 and 7 post mortem) with a total of 136 spot pattern changes $(\mathrm{p} \leq 0.05)$ observed across the three timepoints post mortem. Figure 1a shows a representative gel image scanned to reveal CyDye3 labelled protein features from the pooled sample. Figure $1 \mathrm{~b}$ - $\mathrm{d}$ show representative images of gels scanned to reveal CyDye 5 labelled proteins that were at highest abundance at days 1, 3 and 7 post mortem, respectively.

A principal component analysis (PCA) biplot of the 376 spot variables is presented in Figure 2. The first principal component accounted for $32.46 \%$ of the variation. Samples were separated according to days post mortem along the first component and the greatest contrast was between day 1 and day 7 post mortem. Many spots/proteins in the PCA biplot (Figure 2) were found to co-localise close to samples from days 3 and 7 post mortem, rather than to samples from day 1, indicating their higher abundance at these later timepoints.

\section{Protein identification and abundance profiles of identified spots}

A proteome map for porcine exudate derived from 36 2-D DIGE gels (including the 12 gels presented here), wherein 89 protein spots were successfully identified by MALDI TOF/TOF or LTQ ORBITRAP XL, is presented elsewhere [26]. An online, federated 2-DE database was generated from the spots characterised by MS in the centrifugal drip. This database is available as part of the

Table 1 Mean (SD) of meat quality traits across three timepoints post mortem in the Large White $\mathbf{x}$ Landrace/Large White population

\begin{tabular}{|c|c|c|c|c|c|}
\hline Trait & Day 0 & Day 1 & Day 3 & Day 7 & $P$ \\
\hline$\overline{\mathrm{pH}}$ & $6.43(0.20)^{\#}$ & $5.55(0.13)$ & - & - & \\
\hline Conductivity & - & $6.50(3.05)$ & $10.75(2.65)$ & $11.55(2.44)$ & 0.10 \\
\hline $\mathrm{CIE} \mathrm{L*}$ & - & $55.42(2.01)$ & $54.80(2.62)$ & $54.43(3.95)$ & 0.73 \\
\hline $\mathrm{CIE} a^{*}$ & - & $7.32(0.67)$ & $9.63(3.71)$ & $9.34(2.08)$ & 0.27 \\
\hline $\mathrm{CIE} \mathrm{b*}$ & - & $15.43(0.48)^{a}$ & $15.53(0.46)^{\mathrm{a}}$ & $16.74(1.12)^{b}$ & 0.02 \\
\hline Cook Loss (\%) & - & $33.49(3.40)^{\mathrm{a}}$ & $32.42(2.62)^{a, b}$ & $29.86(3.93)^{b}$ & 0.05 \\
\hline Drip Loss (\%) Day 1-3 & - & - & $3.91(0.38)^{@}$ & - & \\
\hline WBSF (N) & - & $45.67(3.16)^{\mathrm{a}}$ & $40.31(5.20)^{\mathrm{a}}$ & $32.01(3.50)^{b}$ & 0.002 \\
\hline Intramuscular fat (\%) & - & $0.8(0.4)$ & - & - & \\
\hline
\end{tabular}

$\mathrm{L}^{*}=$ lightness; $\mathrm{a}^{*}=$ redness; $\mathrm{b}^{*}=$ yellowness. Warner-Bratzler shear force (WBSF), Newton (N). Intramuscular fat (IMF) (\%). ${ }^{\#} \mathrm{pH}$ recorded at 45 minutes post mortem. ${ }^{\circledR}$ Drip loss obtained by hanging muscle on day 1 post mortem for $48 \mathrm{hrs}$ according to method of Honikel et al. [25]. Significant values are indicated in italics. Within rows, for day 1 to day 7 comparisons means which do not share a common superscript are significantly different. 

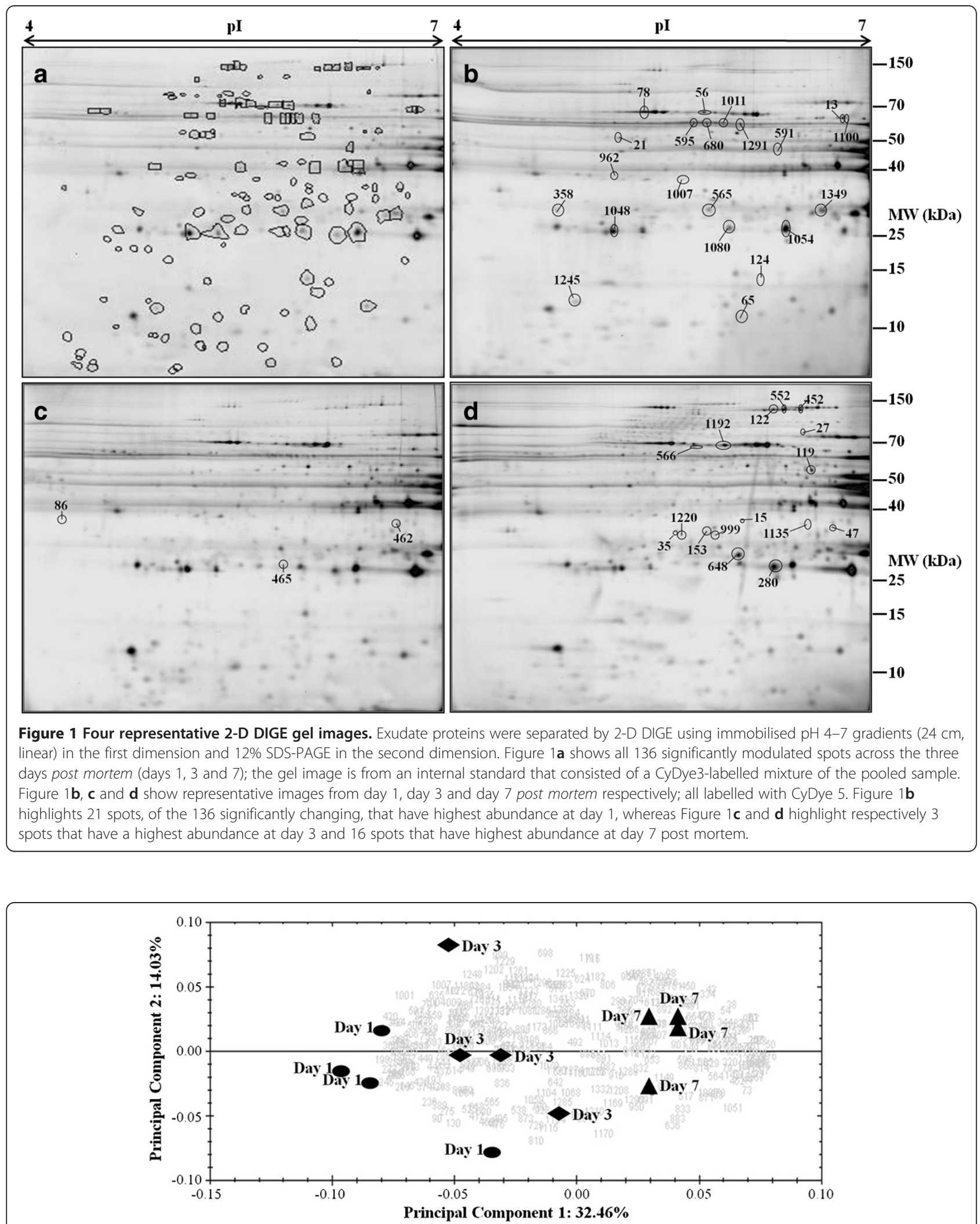

Figure 2 Illustration of the two PCAs carried out using 376 variables (all spots detected) across the three days post mortem (•, day 1 ; $\downarrow$, day $3 ; \boldsymbol{\Lambda}$, day 7). Protein spots are represented by grey numbers. Distinct clustering of the samples by day post mortem is evident from the abundance patterns of these proteins. 
UCD-2DPAGE database under 'Porcine Database' (http:// proteomics-portal.ucd.ie). The proteins/ peptides in 40 spots (corresponding to 52 proteins/peptides) that were identified to be significantly changing in the present comparison were identified using this map. Several proteins/ peptides were identified in more than one spot. The identities of the 40 spots are presented in Table 2 together with the biological process they are associated with, as identified using PANTHER tools [27]. Figure 3 shows a categorisation of proteins characterised by mass spectrometry according to their biological functions.

Table 3 shows the results of the ANOVA on average normalised volumes across days of ageing and the maximum fold change across timepoints (either day 1 versus day 3 , day 1 versus day 7 or day 3 versus day 7). Figure $4 \mathrm{~A}-\mathrm{C}$ shows the expression levels of the 40 identified protein spots at days 1,3 and 7 post mortem, as represented by the mean spot intensity on the DIGE gels. Figure $4 \mathrm{~A} / 1$ and $\mathrm{A} / 2$ graphs data for proteins which are reducing in abundance; Figure $4 \mathrm{~B}$ presents proteins which are increasing in abundance while Figure $4 \mathrm{C}$ shows abundance patterns of spots whose abundance changes are non-linear over the post mortem period.

\section{Confirmation of differential protein expression using Western blotting}

Confirmation of the 2-D DIGE protein expression data was carried out using Western blot analysis for 2 of the spots (AK1 and vinculin) that changed in abundance over the ageing period. The Western blot gels are presented in Figure 5. Three technical replicates were analysed for each sample at each timepoint. The average of the MemCode normalised band density of the three technical replicates was used for statistical comparison. Figure 5 (2-D DIGE) shows representative images for spot 280 (AK1) and spot 452 (vinculin) at each day post mortem (days 1, 3 and 7) with both bi- (A) and three(B) dimensional images displayed.

A double band was detected for AK1 in most of the samples with the lower molecular weight band being more prominent. Following scanning and image analysis it was not possible to obtain optical band intensity for both bands because they were too close, so for statistical analysis, both bands were considered as one. The abundance observed in individual bands did not always correspond precisely with the equivalent spot intensity observed in 2-D DIGE gels, but it is possible to visually observe that the bands at day 1 post mortem display generally a lower band intensity, compared to those at day 7 post mortem with the exception of animal 4.

Four bands were observed for vinculin in each sample. The upper band is the most abundant (with the exception of one sample - lane 3) in the samples at day 1 post mortem. The molecular weight of vinculin is approximately
$120 \mathrm{kDa}$ which is consistent with our observations. This band gradually reduces in abundance at day 3 post mortem to almost disappear at day 7 post mortem. In contrast to this, the smaller bands 2,3 and 4 gradually increase in abundance over the time period. This is shown quantitatively in the graph in Figure 5 (Western blot) which presents the abundance pattern of each vinculin band across the three timepoints and the average of all four bands normalised across the days post mortem. The average density of the four normalised bands of each animal did not change between day 1 and 3 post mortem, but increased between day 3 and day 7 post mortem. The table in the graph shows which group of bands is significantly different across the three timepoints.

The intensities of band 2 of vinculin and the intensity of spot 452 obtained from 2-D DIGE gels show the closest similarity in abundance pattern $\left(R^{2}=0.87\right)$. Bands 3 and 4 show a similar pattern post mortem; this is probably due to the accumulation of degradation products with slightly different molecular weight. This similarity is particularly evident at day 7 post mortem by which time the greatest amount of proteolysis has occurred with consequent higher abundance of degradation products.

\section{Discussion}

Meat ageing influences the taste, tenderness, WHC, colour and juiciness of meat [4,28,29]. Detailed investigation of the biochemical processes occurring during this time improves our understanding of the development of these different traits. Monitoring these processes in an easily accessible substrate is compatible with potential industrial applications for quality biomarkers. Therefore, the aim of the present study was to investigate the changes in the muscle exudate proteome over the normal meat ageing period of seven days in genetically similar pigs from a single population with uniform meat quality characteristics. In this study, several meat quality traits significantly altered in the post mortem period, particularly in later stage of ageing. For example, tenderness improved significantly from day 3 to day 7 , the CIE b* colour parameter of the muscle also changed over the post mortem ageing period and cook loss decreased. These findings illustrate the structural changes that occur within porcine muscle as a result of post mortem ageing and this was also reflected in the proteomic profiles which indicated that 136 spots significantly altered in abundance over the meat ageing period. PCA provided a global view of the structure within the proteome data, indicating that the major features of the dataset reflect the timepoints studied and thus probably the post mortem ageing process. PCA also showed that a higher number of spots/proteins are colocalized on the biplot beside samples at days 3 and 7 post mortem indicating that these spots/proteins are more abundant at these times post mortem. 
Table 2 Biological function of the identified protein/fragment spots in porcine exudate

\begin{tabular}{|c|c|c|c|c|c|c|c|c|}
\hline$\overline{\text { Spot }^{a}}$ & UniProt $^{b}$ & Protein identified & Gene name & Biological process ${ }^{c}$ & Peptides & $\mathrm{pl}^{\mathrm{d}}$ & $\mathrm{MW}(\mathrm{kDa})^{\mathrm{e}}$ & Score $^{f}$ or $^{g}$ \\
\hline 13 & Q08DP0 & Phosphoglucomutase-1 & PGM1 & carbohydrate metabolic process & 2 & 6.4 & 61.6 & $\mathrm{f}_{20.16}$ \\
\hline 13 & Q3ZBZ8 & Stress induced phosphoprotein 1 & STIP1 & immune system process; protein metabolic process; response to stress & 3 & 6 & 62.4 & $f_{30.25}$ \\
\hline 15 & Q5E9A3 & Poly(rC)-binding protein 1 & PCBP1 & $\begin{array}{l}\text { neurological system process; intracellular protein transport; nuclear transport; } \\
\text { induction of apoptosis; protein metabolic process; signal transduction }\end{array}$ & 1 & 6.7 & 37.5 & ${ }^{f} 10.15$ \\
\hline 21 & P20072 & Annexin A7 & ANXA7 & $\begin{array}{l}\text { intracellular protein transport; signal transduction; lipid metabolic process; cell } \\
\text { motion; signal transduction }\end{array}$ & 1 & 6.4 & 50 & ${ }^{f} 10.19$ \\
\hline 27 & Q5XLD3 & Creatine kinase M-type & CKM & muscle contraction; metabolic process & 2 & 6.6 & 43.1 & ${ }^{f} 20.21$ \\
\hline 35 & Q8WZ42 & Titin & TTN & assemblage and functioning of vertebrate striated muscles & 2 & 6 & 3816.2 & $f_{20.15}$ \\
\hline 47 & Q7SIB7 & Phosphoglycerate kinase 1 & PGK1 & carbohydrate metabolic process & 2 & 8 & 44.4 & ${ }^{f} 20.20$ \\
\hline 56 & Q6S4N2 & Heat shock protein 70 & HSPA1B & immune system process; protein metabolic process; response to stress & 20 & 5.6 & 70 & ${ }^{9} 552$ \\
\hline 65 & Q5D862 & Filaggrin-2 & FLG2 & $\begin{array}{l}\text { protein metabolic process; cellular component morphogenesis; } \\
\text { ectoderm development }\end{array}$ & 1 & 8.5 & 247.9 & ${ }^{f} 10.15$ \\
\hline 78 & P19378 & Heat shock cognate 71 & HSPA8 & immune system process; protein metabolic process; response to stress & 18 & 5.2 & 70.8 & ${ }^{9} 290$ \\
\hline 86 & P29700 & $\begin{array}{l}\text { Alpha-2-HS-glycoprotein } \\
\text { (Fragment) }\end{array}$ & AHSG & $\begin{array}{l}\text { immune system process; protein metabolic process; mesoderm development; } \\
\text { skeletal system development }\end{array}$ & 2 & 5.5 & 38.4 & ${ }^{f} 20.32$ \\
\hline 119 & Q29568 & $\begin{array}{l}\text { Phosphopyruvate hydratase } \\
\text { (Fragment) }\end{array}$ & $\mathrm{FH}$ & glycolysis & 2 & 4.6 & 16.1 & $f_{20.25}$ \\
\hline 119 & B1A3A0 & Enolase & ENO3 & glycolysis & 2 & 8.1 & 47.1 & $f_{20.23}$ \\
\hline 119 & P19140 & Alpha-enolase & ENO1 & glycolysis & 2 & 6.4 & 47.2 & ${ }^{f} 20.17$ \\
\hline 122 & Q5XKE0 & Myosin-binding protein C, fast-type & Mybpc2 & $\begin{array}{l}\text { muscle contraction; intracellular protein transport; endocytosis; signal transduction; } \\
\text { cell adhesion }\end{array}$ & 2 & 6 & 127.3 & ${ }^{f} 20.18$ \\
\hline 124 & Q0VCY1 & $\begin{array}{l}\text { Vesicle-associated membrane } \\
\text { protein-associated protein A }\end{array}$ & VAPA & membrane trafficking regulatory protein & 2 & 8.9 & 27.8 & $f_{20.17}$ \\
\hline 153 & B1A3A0 & Enolase & ENO3 & glycolysis & 2 & 8.1 & 47.1 & ${ }^{f} 20.16$ \\
\hline 280 & P00571 & Adenylate kinase isoenzyme 1 & AK1 & nucleobase, nucleoside, nucleotide and nucleic acid metabolic process & 6 & 8.4 & 21.6 & ${ }^{9} 136$ \\
\hline 358 & Q06AB3 & $\begin{array}{l}\text { Ubiquitin carboxyl-terminal } \\
\text { hydrolase isozyme L3 }\end{array}$ & UCHL3 & protein metabolic process & 2 & 4.8 & 26.1 & $f_{20.27}$ \\
\hline 452 & P26234 & Vinculin & VCL & cellular component morphogenesis & 4 & 5.6 & 123.9 & ${ }^{f} 40.17$ \\
\hline 462 & Q2HJ54 & $\begin{array}{l}\text { Phosphatidylinositol transfer } \\
\text { protein alpha isoform }\end{array}$ & PITPNA & visual perception; sensory perception; lipid transport; lipid metabolic process & 2 & 6.1 & 31.8 & $f_{20.21}$ \\
\hline 465 & Q8TCA0 & $\begin{array}{l}\text { Leucine-rich repeat-containing } \\
\text { protein } 20\end{array}$ & LRRC20 & & 2 & 6.1 & 20.5 & $f^{f} 20.28$ \\
\hline 552 & P16419 & Myosin-binding protein C, fast-type & Mybpc2 & $\begin{array}{l}\text { muscle contraction; intracellular protein transport; endocytosis; signal transduction; } \\
\text { cell adhesion; protein metabolic process; cell motion }\end{array}$ & 2 & 6.2 & 126.7 & $f^{f} 20.19$ \\
\hline 565 & Q9TSX9 & Peroxiredoxin-6 & PRDX6 & immune system process; oxygen and reactive oxygen species metabolic process & 15 & 5.7 & 25 & $9_{541}$ \\
\hline 566 & P34930 & Heat shock $70 \mathrm{kDa}$ protein $1 \mathrm{~A}$ & HSPA1A & immune system process; protein metabolic process; response to stress & 1 & 5.5 & 70 & ${ }^{f} 10.15$ \\
\hline 566 & A5A8V7 & Heat shock $70 \mathrm{kDa}$ protein 1-like & HSPA1L & immune system process; protein metabolic process; response to stress & 1 & 6 & 70.3 & ${ }^{f} 10.15$ \\
\hline 566 & 097125 & Heat shock protein 68 & Hsp68 & immune system process; protein metabolic process; response to stress & 2 & 5.6 & 69.7 & ${ }^{f} 20.18$ \\
\hline
\end{tabular}


Table 2 Biological function of the identified protein/fragment spots in porcine exudate (Continued)

\begin{tabular}{|c|c|c|c|c|c|c|c|c|}
\hline 566 & P48720 & Heat shock $70 \mathrm{kDa}$ protein & HSPA1B & immune system process; protein metabolic process; response to stress & 1 & 5.2 & 70.8 & ${ }^{f} 10.16$ \\
\hline 566 & P19120 & Heat shock cognate 71 & HSPA8 & immune system process; protein metabolic process; response to stress & 1 & 5.4 & 71.1 & ${ }^{f_{1} 10.16}$ \\
\hline 566 & Q8T869 & Luminal-binding protein 2 & bip2 & & 1 & 5.1 & 70.4 & $f_{8.17}$ \\
\hline 591 & P08835 & Serum albumin & ALB & transport & 20 & 6.1 & 69.7 & $9_{504}$ \\
\hline 591 & Q710C4 & Adenosylhomocysteinase & $\mathrm{AHCY}$ & nucleobase, nucleoside, nucleotide and nucleic acid metabolic process & 13 & 5.9 & 47.7 & ${ }^{9} 116$ \\
\hline 595 & P81605 & Dermcidin & DCD & defense response & 2 & 6.1 & 11.3 & $f_{20.15}$ \\
\hline 648 & Q3TOP6 & 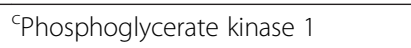 & PGK1 & carbohydrate metabolic process & 2 & 8.5 & 44.5 & $f_{20.28}$ \\
\hline 680 & Q08DP0 & Phosphoglucomutase-1 & PGM1 & carbohydrate metabolic process & 19 & 6.4 & 61.6 & ${ }^{g} 294$ \\
\hline 962 & Q9HC38 & $\begin{array}{l}\text { Glyoxalase domain-containing } \\
\text { protein } 4\end{array}$ & GLOD4 & metabolic process & 2 & 5.4 & 34.8 & $f_{20.18}$ \\
\hline 999 & Q3SX44 & $\begin{array}{l}\mathrm{N}(\mathrm{G}), \mathrm{N}(\mathrm{G}) \text {-dimethylarginine } \\
\text { dimethylaminohydrolase } 2\end{array}$ & DDAH2 & mesoderm development; angiogenesis & 2 & 5.7 & 29.8 & $f_{2} 20.15$ \\
\hline 1007 & P03974 & $\begin{array}{l}\text { Transitional endoplasmic reticulum } \\
\text { ATPase }\end{array}$ & VCP & intracellular protein transport; exocytosis; protein metabolic process & 2 & 5.1 & 89.2 & $\mathrm{f}_{20.18}$ \\
\hline 1011 & A2THZ2 & Albumin (Fragment) & ALB & transport & 2 & 5.9 & 69.6 & $f_{20.17}$ \\
\hline 1048 & P52552 & Peroxiredoxin-2 (Fragment) & PRDX2 & immune system process; oxygen and reactive oxygen species metabolic process & 7 & 4.7 & 14.2 & ${ }^{\mathrm{g}} 204$ \\
\hline 1054 & Q0R678 & DJ-1 protein & PARK7 & $\begin{array}{l}\text { immune system process; nucleobase, nucleoside, nucleotide and nucleic acid } \\
\text { metabolic process; protein metabolic process; response to stress }\end{array}$ & 5 & 6.4 & 19.9 & $f_{50.21}$ \\
\hline 1080 & Q5E946 & DJ-1 protein & PARK7 & $\begin{array}{l}\text { immune system process; nucleobase, nucleoside, nucleotide and nucleic acid } \\
\text { metabolic process; protein metabolic process; response to stress }\end{array}$ & 10 & 6.8 & 20 & ${ }^{g} 276$ \\
\hline 1100 & Q1PC32 & $\begin{array}{l}\text { Triosephosphate isomerase } \\
\text { (Fragment) }\end{array}$ & TPI & fatty acid biosynthesis; gluconeogenesis; glycolysis & 2 & 6 & 21.8 & $\mathrm{f}_{20.19}$ \\
\hline 1100 & Q3ZBZ8 & Stress-induced-phosphoprotein 1 & STIP1 & immune system process; protein metabolic process; response to stress & 2 & 6 & 62.4 & $f_{2} 20.15$ \\
\hline 1135 & Q1KYTO & Beta-enolase & ENO3 & glycolysis & 1 & 8.1 & 47 & $\mathrm{f}_{10.17}$ \\
\hline 1192 & P34930 & Heat shock $70 \mathrm{kDa}$ protein $1 \mathrm{~A}$ & HSPA1A & immune system process; protein metabolic process; response to stress & 6 & 5.5 & 70 & $f_{58.25}$ \\
\hline 1192 & P08835 & Serum albumin & ALB & transport & 4 & 5.8 & 66.8 & $\mathrm{f}_{40.18}$ \\
\hline 1192 & Q04967 & Heat shock $70 \mathrm{kDa}$ protein 6 & HSPA6 & immune system process; protein metabolic process; response to stress & 1 & 5.8 & 71.1 & ${ }^{f} 10.19$ \\
\hline 1220 & Q8WZ42 & Titin & $\overline{T T N}$ & assemblage and functioning of vertebrate striated muscles & 2 & 6 & 3816.2 & $f_{2} 20.16$ \\
\hline 1245 & P69678 & Protein CutA & CUTA & cation transport & 2 & 8.6 & 19 & $\mathrm{f}_{20.19}$ \\
\hline 1291 & $\mathrm{~A} 2 \mathrm{THZ2}$ & Albumin (Fragment) & ALB & transport & 6 & 5.9 & 69.6 & ${ }^{f} 60.27$ \\
\hline 1349 & Q29371 & Triosephosphate isomerase & TPI & fatty acid biosynthesis; gluconeogenesis; glycolysis & 11 & 7.2 & 26.6 & ${ }^{9} 476$ \\
\hline
\end{tabular}

${ }^{\mathrm{a}}$ Spot numbers refer to Figure 1. ${ }^{\mathrm{b}}$ Accession number in the UniProt database. ${ }^{\mathrm{C}}$ Biological process of the proteins obtained using PANTHER analysis [27]. ${ }^{\mathrm{d}}$ Isoelectric point of the protein. ${ }^{\mathrm{e}}$ Molecular weight

of the protein. ${ }^{f}$ TurboSEQUEST or ${ }^{9}$ MASCOT score. These data are also available online in the 2-D PAGE reference protein map produced in our previous study under 'Porcine Database' [http://proteomics-

portal.ucd.ie; Di Luca et al., [26]. 


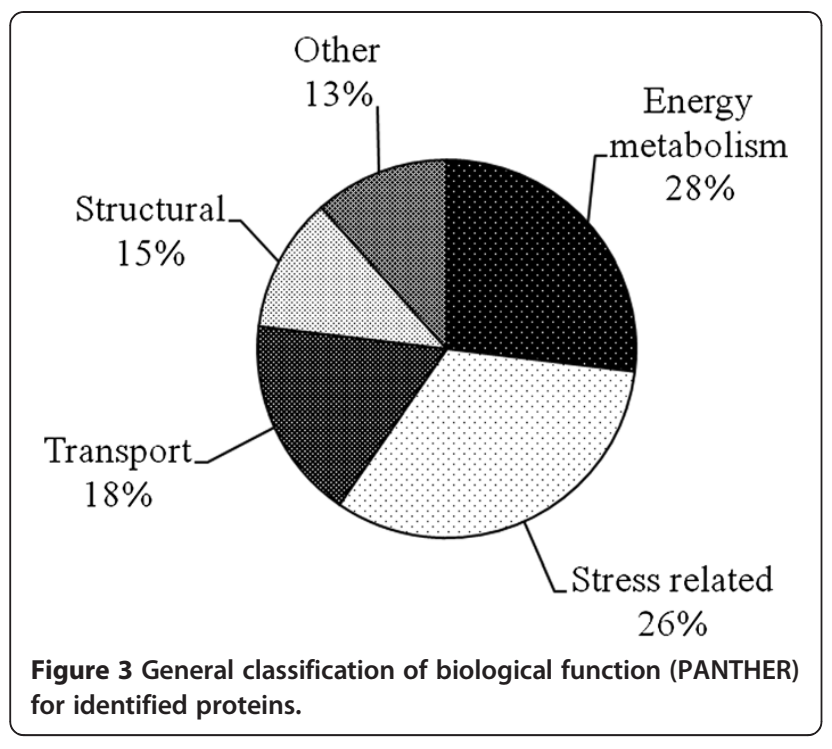

Using a proteome reference map [26], 52 proteins/ peptides in 40 spots were identified and the proteins could be classified generally into four main classes: structural (e.g. titin, vinculin); energy metabolism (e.g. enolase, triosephosphate isomerase), stress related (e.g. stress induced phosphoprotein 1, peroxiredoxin 6) and transport proteins (e.g. protein CutA, albumin). It is known that protein degradation is the major cause of proteome change in post mortem muscle [30]. Many of the spots/ proteins observed in the structural and metabolic categories that were more abundant on day 3 and 7 represent accumulation of fragments of proteolytic processes rather than intact proteins. In contrast, many of the proteins colocalising with day 1 samples and thus tending to decrease in abundance across the ageing period have stress-related functions (e.g. stress induced phosphoprotein 1, peroxiredoxin 6). Below, we will consider the overall patterns in the data for each of the main categories of proteins observed in the study.

\section{Structural proteins}

In the present study, tenderness improved significantly over the ageing period from a shear force value of $46 \mathrm{~N}$ on day 1 post mortem (relatively tough) to $32 \mathrm{~N}$ on day 7 (relatively tender) [31]. Despite the fact that it is well known that the post mortem degradation of structural proteins plays an important role in the development of tenderness, it is still far from established whether any of these proteins are directly responsible for such traits. In the current study, we found that in muscle exudate there is evidence of structural protein degradation. The proteome changes implicate proteolysis of myofibrillar proteins in this process and the consequent generation of fragments (i.e. lower molecular weight compared to parent protein) that accumulate in the exudate over the
Table 3 ANOVA (p value), fold changes (calculated from the mean normalised volumes between the groups that showed the maximum change) and average normalised spot volumes of the $\mathbf{4 0}$ spots characterised by mass spectrometry Spot $^{\mathrm{a}}$ Anova (p) Fold change Mean normalised volumes

\begin{tabular}{llllll}
\cline { 3 - 5 } & & Day $\mathbf{1}$ & Day $\mathbf{3}$ & Day 7 \\
\hline $\mathbf{1 3}$ & 0.009 & 2.2 & $2.525^{\mathrm{a}}$ & $1.68^{\mathrm{ab}}$ & $1.152^{\mathrm{b}}$
\end{tabular}

\begin{tabular}{llllll}
13 & 0.009 & 2.2 & $2.525^{\mathrm{a}}$ & $1.68^{\mathrm{b}}$ & $1.152^{\mathrm{b}}$ \\
\hline $\mathbf{2 1}$ & $1.10 \mathrm{E}-04$ & 2.9 & $0.338^{\mathrm{a}}$ & $0.881^{\mathrm{b}}$ & $0.965^{\mathrm{b}}$ \\
\hline
\end{tabular}

\begin{tabular}{llllll}
\hline $\mathbf{2 1}$ & $7.70 \mathrm{E}-05$ & 2.3 & $2.087^{\mathrm{a}}$ & $1.132^{\mathrm{b}}$ & $0.893^{\mathrm{b}}$ \\
\hline $\mathbf{2 7}$ & 0.013 & 2.2 & $0.775^{\mathrm{a}}$ & $0.846^{\mathrm{a}}$ & $1.681^{\mathrm{b}}$
\end{tabular}

\begin{tabular}{llllll}
\hline $\mathbf{3 5}$ & 0.029 & 2.3 & $0.512^{\mathrm{a}}$ & $0.832^{\mathrm{ab}}$ & $1.163^{\mathrm{b}}$ \\
\hline $\mathbf{4 7}$ & 0.004 & 1.9 & $0.599^{\mathrm{a}}$ & $1.115^{\mathrm{b}}$ & $1.126^{\mathrm{b}}$ \\
\hline
\end{tabular}

\begin{tabular}{llllll}
\hline $\mathbf{4 7}$ & 0.004 & 1.9 & $0.599^{\mathrm{a}}$ & $1.115^{\mathrm{b}}$ & $1.126^{\mathrm{b}}$ \\
\hline $\mathbf{5 6}$ & 0.032 & 1.4 & $1.585^{\mathrm{a}}$ & $1.135^{\mathrm{b}}$ & $1.144^{\mathrm{b}}$
\end{tabular}

\begin{tabular}{llllll}
\hline $\mathbf{5 6}$ & 0.032 & 1.4 & $1.585^{\mathrm{a}}$ & $1.135^{\mathrm{b}}$ & $1.144^{\mathrm{b}}$ \\
\hline $\mathbf{6 5}$ & 0.03 & 1.3 & $1.485^{\mathrm{a}}$ & $1.193^{\mathrm{b}}$ & $1.111^{\mathrm{b}}$
\end{tabular}

\begin{tabular}{llllll}
\hline $\mathbf{7 8}$ & $6.96 \mathrm{E}-04$ & 1.6 & $1.732^{\mathrm{a}}$ & $1.065^{\mathrm{b}}$ & $1.066^{\mathrm{b}}$ \\
\hline 86 & $2.44 \mathrm{E}-04$ & 2.7 & $0.215^{\mathrm{a}}$ & $0.581^{\mathrm{b}}$ & $0.47^{\mathrm{b}}$ \\
\hline
\end{tabular}

\begin{tabular}{llllll}
\hline $\mathbf{8 6}$ & $2.44 \mathrm{E}-04$ & 2.7 & $0.215^{\mathrm{a}}$ & $0.581^{\mathrm{b}}$ & $0.47^{\mathrm{b}}$ \\
\hline $\mathbf{1 1 9}$ & 0.009 & 3.4 & $0.649^{\mathrm{a}^{*}}$ & $1.258^{\mathrm{ab}}$ & $2.213^{\mathrm{b}^{*}}$
\end{tabular}

\begin{tabular}{rrrrrr}
\hline $\mathbf{1 2 2}$ & 0.005 & 2.8 & $0.752^{\mathrm{a}}$ & $0.809^{\mathrm{a}}$ & $2.078^{\mathrm{b}}$ \\
\hline $\mathbf{1 2 4}$ & 0.045 & 2.1 & 1.386 & 1.106 & 0.666
\end{tabular}

\begin{tabular}{llllll}
\hline $\mathbf{1 2 4}$ & 0.045 & 2.1 & 1.386 & 1.106 & 0.666 \\
\hline $\mathbf{1 5 3}$ & 0.002 & 3.4 & $0.733^{\mathrm{a}}$ & $0.607^{\mathrm{a}}$ & $2.049^{\mathrm{b}}$ \\
\hline $\mathbf{2 8 0}$ & 0.021 & 2.7 & $0.716^{\mathrm{a}}$ & $1.802^{\mathrm{b}}$ & $1.954^{\mathrm{b}}$
\end{tabular}

\begin{tabular}{llllll}
\hline $\mathbf{2 8 0}$ & 0.021 & 2.7 & $0.716^{\mathrm{a}}$ & $1.802^{\mathrm{b}}$ & $1.954^{\mathrm{b}}$ \\
\hline $\mathbf{3 5 8}$ & 0.047 & 2.5 & $1.525^{\mathrm{a}}$ & $1.028^{\mathrm{ab}}$ & $0.615^{\mathrm{b}}$
\end{tabular}

\begin{tabular}{llllll}
$\mathbf{3 5 8}$ & 0.047 & 2.5 & $1.525^{\mathrm{a}}$ & $1.028^{\mathrm{ab}}$ & $0.615^{\mathrm{b}}$ \\
\hline $\mathbf{4 5 2}$ & 0.044 & 3.1 & $0.846^{\mathrm{a}}$ & $0.687^{\mathrm{a}}$ & $2.159^{\mathrm{b}}$
\end{tabular}

\begin{tabular}{llllll}
\hline 462 & 0.035 & 1.4 & $0.866^{\mathrm{a}}$ & $1.227^{\mathrm{b}}$ & $1.125^{\mathrm{bH}}$ \\
\hline 465 & 0.046 & 1.8 & $0.874^{\mathrm{b}}$ & $1.532^{\mathrm{b}}$ & $1.112^{\mathrm{b}}$
\end{tabular}

\begin{tabular}{llllll}
\hline $\mathbf{4 6 5}$ & 0.046 & 1.8 & $0.874^{\mathrm{a} @}$ & $1.532^{\mathrm{b} @}$ & $1.112^{\mathrm{ab}}$ \\
\hline 552 & 0.012 & 2.7 & $0.745^{\mathrm{a}}$ & $0.762^{\mathrm{a}}$ & $1.99^{\mathrm{b}}$ \\
\hline
\end{tabular}

\begin{tabular}{llllll}
\hline $\mathbf{5 5 2}$ & 0.012 & 2.7 & $0.745^{\mathrm{a}}$ & $0.762^{\mathrm{a}}$ & $1.99^{\mathrm{b}}$ \\
\hline
\end{tabular}

\begin{tabular}{llllll}
\hline $\mathbf{5 6 5}$ & 0.037 & 1.3 & $1.491^{\mathrm{a}}$ & $1.187^{\mathrm{b}}$ & $1.123^{\mathrm{b}}$ \\
\hline $\mathbf{5 6 6}$ & 0.023 & 1.6 & $1.076^{\mathrm{a}}$ & $1.051^{\mathrm{b}}$ & $1.647^{\mathrm{b}}$
\end{tabular}

\begin{tabular}{llllll}
\hline $\mathbf{5 6 6}$ & 0.023 & 1.6 & $1.076^{\mathrm{a}}$ & $1.051^{\mathrm{a}}$ & $1.647^{\mathrm{b}}$ \\
\hline
\end{tabular}

\begin{tabular}{llllll}
\hline $\mathbf{5 9 1}$ & 0.045 & 1.3 & $1.649^{\mathrm{a}}$ & $1.388^{\mathrm{ab}}$ & $1.273^{\mathrm{b}}$
\end{tabular}

\begin{tabular}{llllll}
\hline $\mathbf{5 9 5}$ & 0.005 & 1.7 & $1.625^{\mathrm{a}}$ & $1.414^{\mathrm{a}}$ & $0.937^{\mathrm{b}}$ \\
\hline
\end{tabular}

\begin{tabular}{llllll}
\hline 648 & 0.027 & 2.9 & $1.019^{\text {a\& }}$ & $0.971^{\mathrm{a}}$ & $2.836^{\mathrm{b}}$ \\
\hline 680 & 0.904 & $1.579^{\mathrm{a}}$ & $1313^{\mathrm{a}}$ & $0.927^{\mathrm{b}}$
\end{tabular}

\begin{tabular}{llllll}
\hline $\mathbf{6 8 0}$ & 0.004 & 1.7 & $1.579^{\mathrm{a}}$ & $1.313^{\mathrm{a}}$ & $0.927^{\mathrm{b}}$ \\
\hline $\mathbf{9 6 2}$ & 0.031 & 1.3 & $1.048^{\mathrm{a}}$ & $0.866^{\mathrm{b}}$ & $0.818^{\mathrm{b}}$
\end{tabular}

\begin{tabular}{llllll}
\hline 999 & $5.30 \mathrm{E}-05$ & 2.2 & $0.789^{\mathrm{a}}$ & $0.901^{\mathrm{a}}$ & $1.697^{\mathrm{b}}$ \\
\hline
\end{tabular}

\begin{tabular}{|c|c|c|c|c|c|}
\hline 1007 & 0.036 & 1.4 & $1.46^{\mathrm{a}}$ & $1.076^{\mathrm{b}}$ & $1.114^{\mathrm{b}}$ \\
\hline 1011 & 0.007 & 1.5 & $1.419^{\mathrm{a}}$ & $1.312^{\mathrm{a}}$ & $0.956^{\mathrm{b}}$ \\
\hline 1048 & 0.009 & 1.4 & $1.462^{\mathrm{a}}$ & $1.299^{\mathrm{a} \S}$ & $1.014^{\mathrm{b}}$ \\
\hline 1054 & 0.019 & 1.3 & $1.589^{\mathrm{a}}$ & $1.446^{\mathrm{ab}}$ & $1.196^{b}$ \\
\hline 1080 & 0.027 & 1.3 & $1.562^{\mathrm{a}}$ & $1.387^{\mathrm{ab}}$ & $1.183^{b}$ \\
\hline 1100 & $8.65 E-06$ & 1.8 & $1.454^{\mathrm{a}}$ & $1.173^{b}$ & $0.807^{c}$ \\
\hline 1135 & 0.033 & 1.5 & 1.066 & 1.084 & 1.566 \\
\hline 1192 & 0.004 & 1.6 & $1.062^{a}$ & $1.385^{b}$ & $1.679^{c}$ \\
\hline 1220 & 0.001 & 3.1 & $0.579^{a}$ & $0.673^{a}$ & $1.823^{b}$ \\
\hline 1245 & 0.014 & 1.5 & $1.339^{\mathrm{a}}$ & $1.216^{\mathrm{ab}}$ & $0.87^{b}$ \\
\hline 1291 & 0.01 & 1.4 & $1.315^{\mathrm{a}}$ & $1.276^{\mathrm{a}}$ & $0.944^{b}$ \\
\hline 1349 & 0.044 & 1.2 & $1.405^{\mathrm{a}}$ & $1.264^{\mathrm{ab}}$ & $1.138^{\mathrm{b}}$ \\
\hline
\end{tabular}

Within rows, different superscripts indicate significantly different means at the $5 \%$ level (following Tukey-Kramer post hoc analysis). * indicates that $p$ value was 0.061 .\# indicates that $p$ value was 0.053 . @ indicates that $p$ value was 0.058 . \& indicate that $p$ value was 0.056 . $\S$ indicate that $p$ value was 0.062 .

4 indicate that $\mathrm{p}$ value was 0.054 . ${ }^{\mathrm{a}} \mathrm{S}$ pot numbers refer to Figure 1 . 


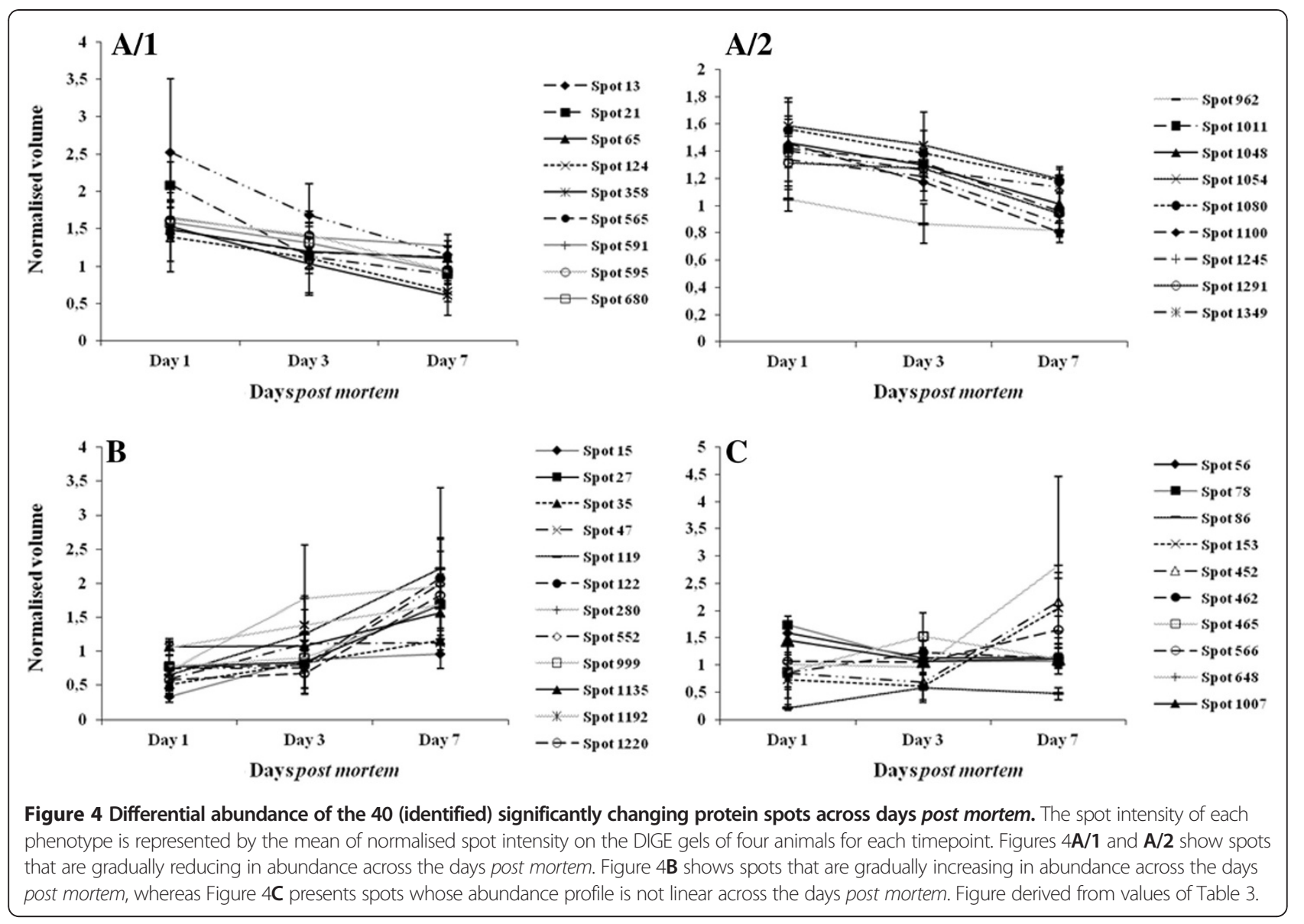

post mortem period. Here, fragments of many structural proteins (titin, vinculin and myosin binding protein $\mathrm{C}$, fast type) increased in abundance over the ageing period. A number of these proteins that have been previously associated with meat quality traits such as WHC and tenderness [9-11,32,33] and Di Luca et al., [26]. Indeed, structural proteins such as titin $[34,35]$ and vinculin $[10,11]$ are known targets of proteolytic enzymes in post mortem muscle. These proteins play important roles within the myofibril, such as being responsible for inter(vinculin) and intra- (titin) myofibril linkages and also in linking myofibrils to the sarcolemma via costameres (vinculin), as well as the attachment of muscle cells to the basal lamina $[3,36]$. Many are very large or giant proteins and components of the insoluble fraction, but with ageing, they are degraded through proteolysis and their fragments increase in abundance in the soluble fraction. As a consequence, released fragments become easily extractable, and in this case increasingly abundant in the centrifugal exudate. This occurs on a timescale comparable with tenderisation and supports the utility of exudate/centrifugal drip for the prediction of traits such as tenderness, which are subject to an important influence of the myofibrillar protein degradome.
On the other hand, both vinculin and myosin were identified in a region of the gel closer to the theoretical molecular weights of these proteins. Vinculin is degraded by the action of the calpain family $[37,38]$ and thus the parent protein might be expected to be proteolysed in the day 7 proteome. However, fragments with a molecular weight very close to the parent protein may start to accumulate, with slightly smaller fragments accumulating also. As is evident from the Western blot analysis, this could be the case with vinculin (Figure 5). The Western blot shows the presence of three bands very close in molecular weight, just smaller than the parent protein. In fact, these are already present at $24 \mathrm{~h}$ post mortem [Figure 5 (Western blot)] indicating proteolysis of this protein commences early in the post mortem period. Vinculin proteolysis has been also observed elsewhere from myofibrillar extracts $[37,38]$.

\section{Energy metabolism proteins}

In the present study, many metabolic enzymes were identified to change over the post mortem period and the majority (e.g. enolase, phosphoglycerate kinase 1) increased in abundance between 1 and 7 days post mortem. Only a few, such as triosephosphate isomerase, decreased 


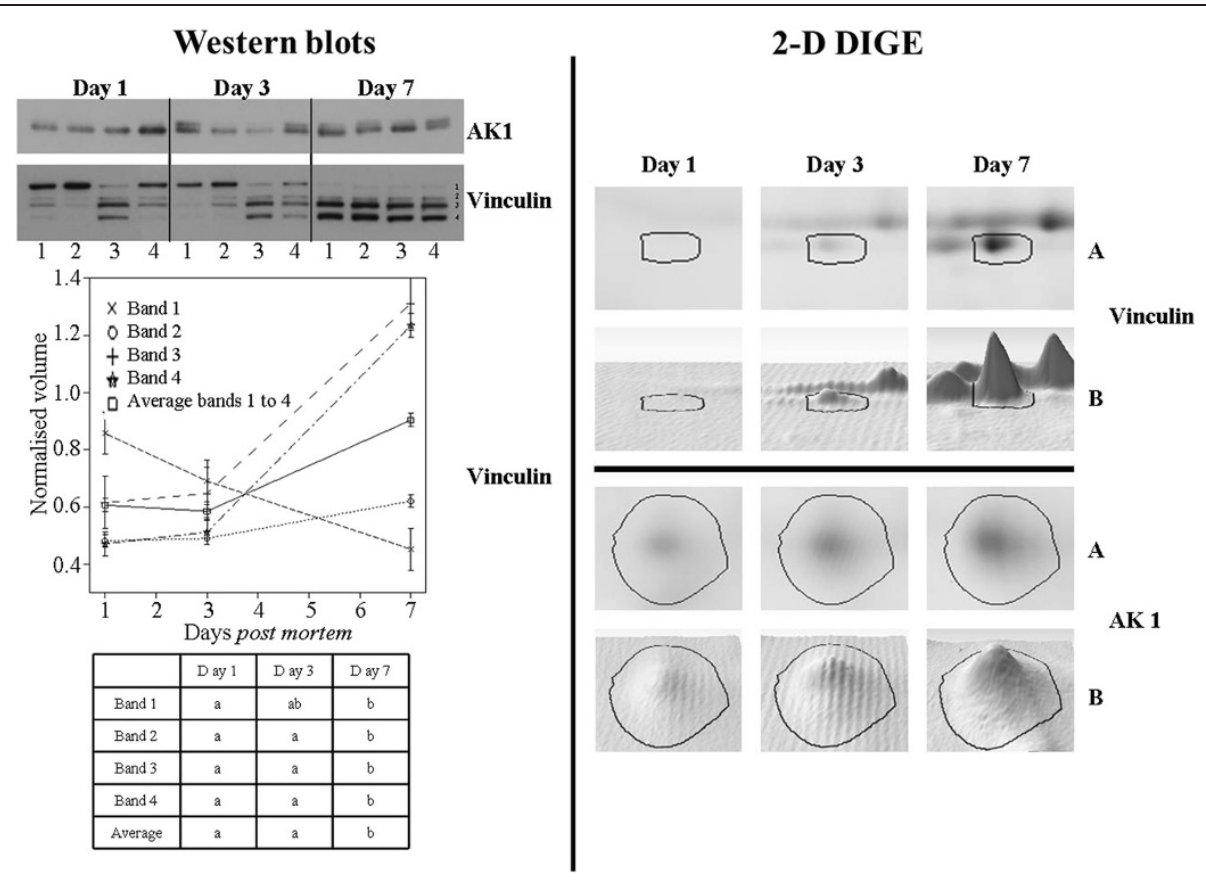

Figure 5 Western blot analysis of adenylate kinase isoenzyme 1 [AK1 (spot 280)] and vinculin (spot 452). Figure 5 (Western blot) shows representative Western blots of AK1 (spot 280) and vinculin (spot 452). Four biological replicates were profiled at each of three timepoints. Numbers ( 1 to 4 ) at the bottom of the image indicate the four animals used in the experiment at each timepoint, each of which was run in an individual gel lane. Three technical replicates were run for each animal and the normalised value was used for statistical analysis. AK 1 membranes show a gradual increment of band intensity with time post mortem. Vinculin blots show 4 bands in each lane that are changing across days post mortem. The graph shows the normalised average band density of vinculin for each band across the days post mortem and the average of all four bands normalised across the days post mortem. Band volumes which are significantly different (Tukey-Kramer analysis) are indicated with a and b. Figure 5 (2-D DIGE) shows representative bi- (A) and three- (B) dimensional expression profile of spots 452 (vinculin) and 280 (AK1) across three timepoints post mortem.

over the ageing period. The enolase spots on the 2-D gel were lower molecular weights than the parent protein 85 $\mathrm{kDA}$ [39], indicating they are fragments. This protein was also observed to degrade up to 7 days post mortem in 1-D SDS PAGE analysis of the same samples [17] and up to 3 days post mortem in an independent porcine muscle study [33]. Phosphoglycerate kinase 1 [40] and Adenylate kinase isoenzyme 1 [41] were identified at molecular weights lower but close to that of the parent protein suggesting minor fragmentation has occurred. Phosphoglycerate kinase 1 was also observed to degrade up to 3 days post mortem in another study [33] and the post mortem degradation of AK1 was also suggested by 1D electrophoresis [17]. A creatine kinase spot was also observed to increase in abundance post mortem, but notably, was identified at a molecular weight approximately twice $(90 \mathrm{kDa})$ that of the parent protein $43 \mathrm{kDa}$, suggesting alterations in the protein's electrophoretic mobility. Post mortem degradation of creatine kinase has been observed previously [17,30,42]. Peptides originating from such markers during ageing have potential as indicators of proteolytic activity and thus meat quality. A triosephosphate isomerase spot was observed to decline in abundance across the ageing period. In this case, the spot probably represents the parent protein. In bovine muscle, triosephosphate isomerase declined in abundance over a time period from slaughter to $24 \mathrm{~h}$ post mortem [43], however in other studies the opposite was observed with the apparently intact protein increasing post mortem and being correlated with Warner Bratzler shear force [11,33]. Minor degradation or differential post-translational modification are difficult to detect using the 2-D approach and may contribute to the lack of consensus among these studies.

\section{Stress related proteins}

Stress related and cellular defence proteins (e.g. stress induced phosphoprotein 1 (STIP1), heat shock protein 70 (HSP70), heat shock cognate 71 (HSC71), DJ 1 protein, ubiquitin, peroxiredoxin 2 , peroxiredoxin 6) showed a decrease in abundance in the exudate proteome from day 1 to day 7 of the ageing period, with a few exceptions (e.g. spot 1192). Heat shock proteins (HSPs) have a background level of activity which can increase when cells are exposed to stresses [44], acting to slow the process of cellular death. [45]. These molecular processes may retard 
meat ageing $[4,46]$ and by extension affect meat quality traits that are modulated over the ageing period, such as tenderness [12,47] and colour [48]. Following a peak in abundance, many subsequently diminish [49]. In the present study, HSPs may be less abundant in protein extracts at later timepoints because their interaction with unfolded and denatured myofibrillar proteins could cause their translocation from the sarcoplasmic to the myofibrillar fraction $[45,50]$. HSPs are also known to translocate to the nucleus from the cytoplasm as a response to stress [51]; in early post mortem muscle hypoxia and rigor onset are significant stressors. In the present study, yellowness $\left(\mathrm{CIE} \mathrm{b}^{*}\right)$ increased with ageing, although lightness (CIE $\left.\mathrm{L}^{*}\right)$ and redness $\left(\mathrm{CIE} \mathrm{a}^{*}\right)$ were not affected. Because the reflectance aspects of meat colour are modulated by protein denaturation, interaction with heat shock proteins may defer changes in the structure of pigment and myofibrillar proteins. As HSPs decline in abundance over time, this may contribute to minor alterations in muscle colour [52].

Several non HSP stress-related proteins also declined in abundance in the muscle exudate (e.g. peroxiredoxin 2 and 6, ubiquitin) between 1 and 7 days post mortem. Peroxiredoxin 2 and peroxiredoxin 6 are members of the ubiquitous family of peroxiredoxins [53]. Peroxiredoxin 2 has a dual function; as a peroxidase and as a molecular chaperone $[54,55]$. Jia et al., $[49,56]$ observed that, at early timepoints post mortem, peroxiredoxin 6 is more abundant in tender meat. Jia et al. [49] also monitored peroxiredoxin 2 and 6 in bovine muscle from slaughter up to 24 hours post mortem and showed that both increased in abundance over this time period. Our findings in pork suggest that after 24 hours, the abundance of these proteins declines. Ubiquitin also decreased after 1 day post mortem. Ubiquitin mRNA expression has been observed to increase in skeletal muscle after several trauma conditions [57]. Our findings support the growing consensus that stress-related proteins play important roles in the meat ageing process by helping to prevent degradation and structural damage of proteins from apoptotic processes in muscle cells $[4,46]$.

\section{Conclusion}

Three key groups of proteins were identified (stress related proteins, metabolic enzymes and structural proteins), that were altered in abundance over the post mortem ageing period. Emergent features of the data included a gradually increasing spot abundance post mortem for metabolic, as well as structural protein fragments. Proteolysis likely plays a major role in explaining inverse abundance patterns for parent proteins and their fragments (e.g. enolase, titin). The other prominent feature of the data was that stress related proteins declined in abundance/ moved away from the sarcoplasmic fraction [45] across the ageing period. Improvement in meat quality as a result of meat ageing is likely to be associated with these parallel molecular events. Monitoring these changes is usually accomplished using myofibrillar or sarcoplasmic proteomic fractions. Our observations in a more accessible substrate, i.e. muscle exudate, provide information that is complementary to previous studies e.g. several of the proteins characterised in the current study have also been correlated to quality elsewhere (e.g. vinculin for WHC, peroxiredoxin 6 for tenderness). Such protein biomarkers hold potential for application ultimately by pork processors to monitor fresh meat quality at relevant timepoints in the slaughterhouse.

\section{Materials and methods}

\section{Animal sampling and meat quality measurements}

Thirty one halothane free Large White $\times$ Landrace/Large White female pigs (gilts), aged six months and at a liveweight of approximately $100 \mathrm{~kg}$, were electrically stunned and then slaughtered under controlled conditions in an EU licensed pilot-scale abattoir at Teagasc, Food Research Centre Ashtown, Dublin. Sample collection and the protocol for the extraction of exudate from muscle tissue following centrifugation (centrifugal drip) are described elsewhere [17]. The protein concentration of all samples used in this study was determined in triplicate according to a modified Bradford assay protocol using a BSA standard [58].

Several technological quality measurements were taken post slaughter such as loin $\mathrm{pH}$, temperature, colour of the longissimus thoracis et lumborum (LTL) muscle and drip loss, as described previously [17], allowing muscle displaying impaired quality characteristics such as pale, soft, exudative meat (PSE), dark, firm, dry meat (DFD), high drip loss and low drip loss to be excluded from this study. Four animals not displaying signs of PSE, DFD, high drip loss and low drip loss were considered as relatively uniform in the quality traits assessed and were selected for this study. Meat quality characteristics such as conductivity, CIELAB colour parameters, Cook loss (\%) and Warner Bratzler shear force (WBSF) were measured at day 1, 3 and 7 post mortem as described in Di Luca et al. [17]. Exudate was collected from the muscle at days 1,3 \& 7 post mortem for proteome evaluation following a modified protocol of Bouton, Harris, and Shorthose [59], as reported in [17].

\section{Proteomic analysis \\ 2-D DIGE}

Exudate samples from muscle of the four selected animals at days 1, 3 and 7 post mortem (total of 12 samples) were compared in one experiment using 2-D DIGE (Ettan DIGE, Ge Healthcare, UK). Each sample was normalised to a protein concentration of $10 \mathrm{mg} / \mathrm{ml}$ with DIGE lysis Buffer [9.5 M Urea (USB, Cleveland, OH); $2 \%$ CHAPS, pH 8.5]. Each CyDye [Cy3 and Cy5 dye fluors 
(GE Healthcare)] stock was resuspended in 99.8\% anhydrous N, N-Dimethylformamide (DMF, Sigma, St. Louis, $\mathrm{MO}$ ) reaching a final dye concentration of $1 \mathrm{mM}$. A working solution of 400 pmol of each CyDye was generated by dilution of the stock with DMF. Each sample was labelled with 400 pmol of Cy5 dye fluor (GE Healthcare), using the minimal labelling technique [35]. A pool, to be used as an internal standard, was generated from equal amounts of 36 samples including the 12 samples analysed here and this pool was bulk labelled with Cy3 dye fluor (400 pmol of CyDye per $50 \mu \mathrm{g}$ of protein; GE Healthcare). The samples and the pool were separately mixed and left on ice for $30 \mathrm{~min}$ in the dark. The reaction was stopped by adding $1 \mu \mathrm{l}$ of $10 \mathrm{mM}$ lysine (Sigma) and samples were further processed according to manufacturer's instructions.

For each gel, $50 \mu \mathrm{g}$ of labelled protein [in 2X sample buffer (9.5 M Urea; 2\% CHAPS; 2\% DTT; 1.6\% Pharmalyte $\mathrm{pH} 3-10)$ ] from an individual sample plus $50 \mu \mathrm{g}$ of labelled protein from the pool (in $2 \mathrm{X}$ sample buffer) were mixed together and the volume was adjusted to $450 \mu \mathrm{l}$ with rehydration buffer (8 M Urea; 0.5\% CHAPS; 0.2\% DTT; 0.2\% Pharmalyte pH 3-10). Passive in-gel rehydration using immobilised DryStrips $\mathrm{pH} 4-724 \mathrm{~cm}$ (GE Healthcare) gradients was carried out overnight in the dark. The isoelectric focusing was performed using Ettan IPG Phor3 (GE Healthcare) under the following conditions: $3500 \mathrm{~V}$ at $75000 \mathrm{VHrs}$; gradient $8000 \mathrm{~V}$ for $10 \mathrm{~min}$; $8000 \mathrm{~V}$ for 1 Hour and holding step at $100 \mathrm{~V}$. After isoelectric focusing, the IPG strips were equilibrated for $15 \mathrm{~min}$ in reducing equilibration buffer [6 $\mathrm{M}$ Urea, $50 \mathrm{mM}$ TrisHCl pH 8.8 (USB), 30\% (v/v) Glycerol, 2\% (w/v) SDS, $1 \%(\mathrm{w} / \mathrm{v}) \mathrm{DDT})]$ and subsequently alkylated for $15 \mathrm{~min}$ in alkylation equilibration buffer $\left[\left(\begin{array}{llll}6 & \mathrm{M} & \text { Urea, } & 50 \mathrm{mM}\end{array}\right.\right.$ TrisHCl pH 8.8, 30\% (v/v) Glycerol, 2\% (w/v) SDS, 2.5\% $(\mathrm{w} / \mathrm{v})$ iodoacetamide (Sigma)]. The proteins were further separated in the second dimension using a $12 \%$ SDSPAGE gel in Tris-Glycine running buffer [25 mM Tris; $192 \mathrm{mM}$ Glycine (USB); $0.1 \%$ (w/v) SDS] at $15^{\circ} \mathrm{C}$ overnight in the dark by means of a PROTEAN Plus Dodeca Cell (Bio-Rad, Hercules, CA).

\section{Image analysis}

The DIGE gels were scanned at $100 \mu \mathrm{m}$ resolution using a Typhoon scanner 9200 (GE Healthcare) at two different wavelengths (CyDye3, green laser $532 \mathrm{~nm}$ and CyDye5, red laser $633 \mathrm{~nm}$ ). Two images per gel were obtained (24 in total). The scanned images were analyzed using Progenesis SameSpots (Nonlinear Dynamics, Durham, NC). Spots were both automatically and manually detected to avoid undetected or incorrectly detected spots. The protein spots detected in each image were automatically linked between the two images per gel. The most representative gel was selected as reference and then all the gels were matched to it. Following spot detection and matching, spot volume were normalised and statistically analysed.

\section{Preparative 2-D PAGE for protein spot identification}

Preparative gels (from different phenotypes) were run loading four different amounts of protein (200 $\mu \mathrm{g}$, $400 \mu \mathrm{g}, 500 \mu \mathrm{g}, 600 \mu \mathrm{g})$ using the same separation conditions previously described for 2-D DIGE. These gels were fixed overnight in $10 \%$ acetic acid and $40 \%$ ethanol and then stained with a PlusOne silver stain kit (GE Healthcare), compatible with downstream mass spectrometry analysis. The spots of interest identified by the DIGE study were matched to the silver stained gels and manually excised. Each gel plug was destained and washed using Ettan Digester (Amersham Biosciences) and then in-gel tryptic digestion and peptide extraction was carried out as follows. $50 \mu \mathrm{l}$ volume of a 1:1 solution of $\mathrm{K} 3 \mathrm{Fe}(\mathrm{CN}) 6$ (Sigma) and Na2S2O3 (Sigma) was added to the gel plug and incubated for $20 \mathrm{~min}$ at $20^{\circ} \mathrm{C}$ in a shaker. Plugs were washed several times with 50\% $\mathrm{MeOH}$ (Sigma), $50 \mathrm{mM}$ NH4HCO3 (Sigma) and incubated at $20^{\circ} \mathrm{C}(10 \mathrm{~min})$ and $37^{\circ} \mathrm{C}(15 \mathrm{~min})$; washed in $20 \mathrm{mM}$ NH4HCO3 (Sigma) and in $70 \%$ of $\mathrm{ACN}$, both incubated at $37^{\circ} \mathrm{C}$ with shaking $(15 \mathrm{~min})$. Next, the liquid was removed from the plate and $25 \mu \mathrm{l}$ of trypsin (Sequencing Grade Modified, Promega, Madison, NJ)

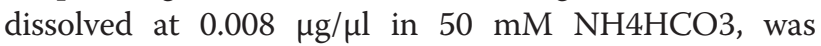
added to each sample and incubated in the dark at $37^{\circ} \mathrm{C}$, while shaking, overnight. Peptides were extracted with two different concentrations of ACN/0.2\% TFA (Sigma) (30\% \& $70 \%$ ) for $10 \mathrm{~min}$ at $37^{\circ} \mathrm{C}$, with shaking. Peptides extracted at both concentrations were concentrated in a speed vac (Eppendorf Concentrator 5301, Germany) at $45^{\circ} \mathrm{C}$ to dry.

\section{MALDI-TOF mass spectrometric analysis}

MALDI-TOF mass spectrometric analysis was carried out with a 4800 plus MALDI TOF/TOF Analyzer (Applied Biosystems, Foster City, CA, USA). The lyophilized peptides were dissolved in matrix buffer (70\% ACN, $0.1 \%$ TFA in MilliQ water), mixed with $3 \mathrm{mg} / \mathrm{mL}$ of alphacyano 4-hydroxycinnamic acid in 50\% ACN/0.1\% TFA (in MilliQ water) and spotted onto a 384-well MALDI target plate (Applied Biosystems). Peptide masses were acquired over a range from 800 to $4000 \mathrm{~m} / \mathrm{z}$, with a focus mass of $2000 \mathrm{~m} / \mathrm{z}$. MS spectra were acquired by 2000 laser shots from an Nd:YAG laser operating at $355 \mathrm{~nm}$ and $200 \mathrm{~Hz}$. Calibration was performed using peptide standards (masses 900-2400 m/z, Applied Biosystems). After measuring all samples in the MS mode, a maximum of 12 precursors per spot were selected for subsequent fragmentation by collision-induced dissociation. The resulting spectra were processed and analysed using the Global 
Protein Server (GPS Explorer) workstation (Applied Biosystems), which uses internal MASCOT (Matrix Sciences) software for matching MS and MS/MS data against databases of in silico digested proteins. The data obtained were screened against a porcine database (UniSprot-porcine; 06/11/09) and all entries database (Sprot; 14/12/09). The following analysis settings were used for the identification of peptides and proteins: (i) precursor tolerance: $30 \mathrm{ppm}$, (ii) $\mathrm{MS} / \mathrm{MS}$ fragment tolerance: $0.2 \mathrm{Da}$, (iii) maximum missed cleavages: 2 and (iv) variable modifications: oxidation of methionine, cysteine carbamidomethylation. Protein identifications were considered correct calls when the confidence interval (CI) was greater than $95 \%$ and a minimum of 2 peptides could be attributed per protein.

\section{LC-MS/MS analysis}

The spots for which an unambiguous identification could not be obtained by MALDI mass spectrometry were re-analysed by nano-ESI LC-MS/MS.

A Thermo Scientific LTQ ORBITRAP XL mass spectrometer was connected to an Exigent NANO LC.1DPLUS chromatography system incorporating an auto-sampler. Tryptic peptides were resuspended in $12 \mu \mathrm{l}$ of $0.1 \%$ formic acid. Each sample was loaded onto a Biobasic C18 PicofritTM column (100 mm length, $75 \mathrm{~mm} \mathrm{ID)}$ and was separated by a $25 \mathrm{~min}$ reverse phase increasing acetonitrile gradient $(0-50 \%$ acetonitrile for $11 \mathrm{~min})$ at a flow rate of $30 \mathrm{~nL}$ min-1. The mass spectrometer was operated in positive ion mode with a capillary temperature of $200^{\circ} \mathrm{C}$, a capillary voltage of $9 \mathrm{~V}$, a tube lens voltage of $100 \mathrm{~V}$ and with a potential of $1800 \mathrm{~V}$ applied to the frit. All data was acquired with the mass spectrometer operating in automatic data dependent switching mode. A high resolution MS scan (300-2000 m/z) was performed using the Orbitrap to select the 5 most intense ions prior to MS/MS analysis using the Ion trap.

TurboSEQUEST (Bioworks Browser 3.3.1 SP1; Thermo Scientific, UK) was used to search the porcine subset of the Uniprot Swissprot/Trembl fasta database (December 2009) and the Uniprot/Swissprot database (March 2009) for fully and partially tryptic peptides. Each peptide used for protein identification met specific SEQUEST parameters, i.e. cross-correlation values of $\geq 1.9, \geq 2.5, \geq 3$.2 and $\geq 3.2$ for single, double, triple and quadruple charged peptides, respectively, and a peptide probability of $<0.001$. Oxidation of methionine, cysteine carbamidomethylation and phosphorylation on $\mathrm{S}, \mathrm{T}$, and $\mathrm{Y}$ amino acids were used as variable modifications.

\section{Western blot analysis}

To confirm the 2-D DIGE results for the post mortem comparison, samples were separated by SDS PAGE using the Novex ${ }^{\circledR}$ Gel protocol with 12\% Bis-Tris Mini Gels $\left(\right.$ Novex $^{\circledR}$ Invitrogen, Carlsbad, CA, USA). Two proteins [vinculin and adenylate kinase isoenzyme 1 (AK1)] were selected for validation by Western blot based on spot abundance patterns and for each of them the experiment was repeated 3 times. Ten micrograms of protein were loaded in each lane for the samples that were later incubated with the antibody mouse monoclonal anti vinculin (7 F9) (Santa Cruz, USA, sc-73614). Five $\mu$ g of proteins were loaded in each lane for the samples that were incubated with the antibody mouse monoclonal anti adenylate kinase 1 (AK1) (Santa Cruz, USA, sc 100354). Proteins were electrophoretically transferred to $0.2 \mu \mathrm{m}$ nitrocellulose membranes (Invitrogen, USA). To ensure successful transfer of proteins and to allow for accurate quantitation of protein load, membranes that were to be used for validation of differential expression of protein between the three days post mortem were stained using MemCode Reversible Protein Stain kit for nitrocellulose membranes (Pierce, NY). The stained membranes were then scanned using a densitometric scanner (GS-800 Bio-Rad, USA). The stain was then removed using MemCode Stain Eraser, washed with ultrapure water and then blocked with 5\% non-fat dry milk (Cell Signaling Technology) (Antharavally, Carter, Bell \& Krishna Mallia, 2004). After blocking, the membranes were incubated overnight $\left(2-8^{\circ} \mathrm{C}\right)$ in a sealed bag with the primary antibodies. The dilutions of the primary antibodies used to detect the targeted proteins are: 1:1000 for vinculin and 1:200 for AK1. The membranes were then incubated with the secondary antibodies for $1 \mathrm{~h}$. For both primary anybodies, the secondary antibody used was polyclonal donkey anti-mouse IgG HPR conjugated (1:2500, SA1 - 100, ABR Affinity BioReagents, USA). Membranes were finally subjected to electrochemiluminescent detection using ECL Plus Western Blotting Detection Reagent (GE Healthcare) and then scanned using a densitometric scanner (GS-800 Bio-Rad). Average band density was determined using Quantity one 4.5.2 software (Bio-Rad, USA). The average band density was then normalised to the average density of the lane to control for any loading inaccuracies [60].

\section{Data analysis}

2-D DIGE Following spot detection and matching across the 2-D DIGE gels, statistical analysis of the log standardized abundance changes between groups was performed using the software incorporated in Progenesis SameSpots. The normalised volume of a spot was compared across timepoints using one way ANOVA. Principal Component Analysis (PCA) was subsequently applied to visualize these differences between samples including the significantly changing spots $[61,62]$.

Differential abundance of proteins across timepoints was expressed as a fold change and calculated from the mean normalised volumes between the highest of the changes between the three timepoints. The biological 
function of the proteins identified was assigned using ontology tools in PANTHER [27].

Western blotting In order to examine the impact of ageing on the exudate proteome, the normalised average band density obtained from the samples stained by Western blotting with vinculin and AK1 were modelled using a repeated measures ANOVA procedure in SAS v.9.1 (SAS Institute, Carry, NC, USA). Timepoint was included in each model as a fixed effect and animal as a random effect. Each band - and additionally in the case of vinculin; the sum of all 4 bands - was analysed in a separate model. For significant bands, Tukey-Kramer post hoc analysis was applied to contrast timepoints.

\section{Abbreviations \\ HAL: Halothane gene; LTL: Longissimus thoracis et lumborum; PCA: Principal component analysis; PSE: Pale, soft, exudative; SAS: Statistical analysis system; STIP: Stress induced phosphoprotein; TPI: Triose phosphate isomerase; WHC: Water holding capacity.}

\section{Competing interests}

The authors declare that they have no competing interests.

\section{Authors' contributions}

$\mathrm{RH}, \mathrm{AMM}, \mathrm{GE}$ and $\mathrm{ADL}$ conceived and designed the study. ADL carried out laboratory work, collation of data, data analysis and prepared the first draft of the manuscript. ADL and $\mathrm{RH}$ carried out animal sampling and determination of meat phenotypes. AMM interpreted meat quality phenotypes. ADL and GE carried out bioinformatic data analysis and interpretation of mass spectrometry data. $\mathrm{ADL}, \mathrm{GE}, \mathrm{AMM}, \mathrm{RH}$ participated in interpretation of data, editing the manuscript and development of the final draft. All authors agreed with the final manuscript.

\section{Acknowledgements}

We wish to thank Paula Reid for assistance with statistical analysis, Dr Peadar Lawlor for supply of animals. Access to and use of instrumentation of the UCD Conway Mass Spectrometry Resource is gratefully acknowledged. This research was funded through the Irish National Development Plan through the Food Institutional Research Measure of the Department of Agriculture, Food and the Marine, Project 06RDNUIG470.

\section{Author details}

${ }^{1}$ Teagasc Food Research Centre, Ashtown, Dublin 15, Ireland. ${ }^{2}$ Mass Spectrometry Resource, UCD Conway Institute of Biomolecular and Biomedical Research, Belfield, Dublin 4, Ireland.

Received: 11 December 2012 Accepted: 13 March 2013

Published: 20 March 2013

\section{References}

1. Rosenvold K, Andersen HJ: Factors of significance, for pork quality - a review. Meat Sci 2003, 64:219-237.

2. Cameron ND: Genetic and phenotypic parameters for carcass traits, meat and eating quality traits in pigs. Livest Prod Sci 1990, 26:119-135.

3. Koohmaraie M: Biochemical factors regulating the toughening and tenderization processes of meat. Meat Sci 1996, 43:193-201.

4. Ouali A, Herrera-Mendez CH, Coulis G, Becila S, Boudjellal A, Aubry L, Sentandreu MA: Revisiting the conversion of muscle into meat and the underlying mechanisms. Meat Sci 2006, 74:44-58.

5. Cheng Q, Sun D-W: Factors affecting the water holding capacity of red meat products: a review of recent research advances. Crit Rev Food Sci Nutr 2008, 48:137-159.

6. Huff-Lonergan E, Lonergan SM: Mechanisms of water holding capacity of meat: the role of post mortem biochemical and structural changes. Meat Sci 2005, 71:194-204.
7. Koohmaraie M: The role of $\mathrm{Ca} 2+-$ dependent proteases (calpains) in post mortem proteolysis and meat tenderness. Biochimie 1992, 74:239-245.

8. Zhang WG, Lonergan SM, Gardner MA, Huff-Lonergan E: Contribution of post mortem changes of integrin, desmin and [mu]-calpain to variation in water holding capacity of pork. Meat Sci 2006, 74:578-585.

9. Kristensen L, Purslow PP: The effect of ageing on the water holding capacity of pork: role of cytoskeletal proteins. Meat Sci 2001, 58:17-23.

10. Melody JL, Lonergan SM, Rowe LJ, Huiatt TW, Mayes MS, Huff-Lonergan E: Early post mortem biochemical factors influence tenderness and water holding capacity of three porcine muscles. J Anim Sci 2004, 82:1195-1205.

11. Hwang IH, Park BY, Kim JH, Cho SH, Lee JM: Assessment of post mortem proteolysis by gel based proteome analysis and its relationship to meat quality traits in pig longissimus. Meat Sci 2005, 69:79-91.

12. Bernard C, Cassar-Malek I, Le Cunff M, Dubroeucq H, Renand G, Hocquette J-F: New indicators of beef sensory quality revealed by expression of specific genes. J Agric Food Chem 2007, 55:5229-5237.

13. Mullen AM, Stapleton PC, Corcoran D, Hamill RM, White A: Understanding meat quality through the application of genomic and proteomic approaches. Meat Sci 2006, 74:3-16.

14. Hollung K, Veiseth E, Jia X, Færgestad EM, Hildrum Kl: Application of proteomics to understand the molecular mechanisms behind meat quality. Meat Sci 2007, 77:97-104.

15. Bendixen E, Danielsen M, Hollung K, Gianazza E, Miller I: Farm animal proteomics - a review. J Proteomics 2011, 74:282-293.

16. Paredi G, Raboni S, Bendixen E, de Almeida AM, Mozzarelli A: "Muscle to meat" molecular events and technological transformations: the proteomics insight. J Proteomics 2012, 75:4275-4289.

17. Di Luca A, Mullen AM, Elia G, Davey G, Hamill RM: Centrifugal drip is an accessible source for protein indicators of pork ageing and water holding capacity. Meat Sci 2011, 88:261-270.

18. Görg A, Weiss W, Dunn MJ: Current two dimensional electrophoresis technology for proteomics. Proteomics 2004, 4:3665-3685.

19. Rabilloud T: Two dimensional gel electrophoresis in proteomics: old, old fashioned, but it still climbs up the mountains. Proteomics 2002, 2:3-10.

20. Lametsch R: 'Meatomics'. In 55th International Congress of Meat Science and Technology (ICOMST); August 16-21, 2009. Denmark, Copenhagen; 2009.

21. Lametsch $\mathrm{R}$, Bendixen E: Proteome analysis applied to meat science: characterizing post mortem changes in porcine muscle. J Agric Food Chem 2001, 49:4531-4537.

22. Alban A, Olu S, David SO, Bjorkesten L, Andersson C, Sloge E, Lewis S, Currie I: A novel experimental design for comparative two dimensional gel analysis: Two dimensional difference gel electrophoresis incorporating a pooled internal standard. Proteomics 2003, 3:36-44.

23. Ünlü M, Morgan ME, Minden JS: Difference gel electrophoresis. A single gel method for detecting changes in protein extracts. Electrophoresis 1997, 18:2071-2077.

24. Tonge R, Shaw J, Middleton B, Rowlinson R, Rayner S, Young J, Pognan F, Hawkins E, Currie I, Davison M: Validation and development of fluorescence two dimensional differential gel electrophoresis proteomics technology. Proteomics 2001, 1:377-396.

25. Honikel KO: Reference methods for the assessment of physical characteristics of meat. Meat Sci 1998, 49:447-457.

26. Di Luca A, Elia G, Mullen A, Hamill R: 2-D DIGE proteomic analysis of early post mortem muscle exudate highlights the importance of the stress response for improved water-holding capacity of fresh pork meat. Proteomics. in press.

27. Thomas PD, Kejariwal A, Guo N, Mi H, Campbell MJ, Muruganujan A Lazareva-Ulitsky B: Applications for protein sequence-function evolution data: $\mathrm{mRNA}$ /protein expression analysis and coding SNP scoring tools. Nucleic Acids Res 2006, 34:645-650.

28. Farouk MM, Mustafa NM, Wu G, Krsinic G: The "sponge effect" hypothesis: An alternative explanation of the improvement in the waterholding capacity of meat with ageing. Meat Sci 2012, 90:670-677.

29. Huff Lonergan E, Zhang W, Lonergan SM: Biochemistry of post mortem muscle - Lessons on mechanisms of meat tenderization. Meat Sci 2010, 86:184-195.

30. Lametsch $R$, Roepstorff $P$, Bendixen E: Identification of protein degradation during post mortem storage of pig meat. J Agric Food Chem 2002, 50:5508-5512

31. Hamill R, McBryan J, McGee C, Mullen A, Sweeney T, Talbot A, Cairns M, Davey G: Functional analysis of muscle gene expression profiles 
associated with tenderness and intramuscular fat content in pork. Meat Sci 2012, 92:440-450.

32. Morrison EH, Mielche MM, Purslow PP: Immunolocalisation of intermediate filament proteins in porcine meat. Fibre type and muscle specific variations during conditioning. Meat Sci 1998, 50:91-104.

33. Lametsch R, Karlsson A, Rosenvold K, Andersen HJ, Roepstorff P, Bendixen E: Post mortem proteome changes of porcine muscle related to tenderness. J Agric Food Chem 2003, 51:6992-6997.

34. Paterson BC, Parrish FCJ, Stromer MH: Effects of salt and pyrophosphate on the physical and chemical properties of beef muscle. J Food Sci 1988, 53:1258-1265.

35. Geesink GH, Koohmaraie M: Effect of calpastatin on degradation of myofibrillar proteins by mu-calpain under post mortem conditions. J Anim Sci 1999, 77:2685-2692.

36. Hattori A, Wakamatsu J-i, Ishii T, Kuwahara K, Tatsumi R: A novel 550-kDa protein in skeletal muscle of chick embryo: purification and localization. Biochim Biophys Acta 1995, 1245:191-200.

37. Taylor RG, Geesink GH, Thompson VF, Koohmaraie M, Goll DE: Is Z-disk degradation responsible for post mortem tenderization? J Anim Sci 1995 73:1351-1367

38. Laville E, Sayd T, Morzel M, Blinet S, Chambon C, Lepetit J, Renand G, Hocquette JF: Proteome changes during meat aging in tough and tender beef suggest the importance of apoptosis and protein solubility for beef aging and tenderization. J Agric Food Chem 2009, 57:10755-10764.

39. Farrar WW, Deal WC: Purification and properties of pig liver and muscle enolases. J Protein Chem 1995, 14:487-497.

40. Watson HC, Walker NPC, Shaw PJ, Bryant TN, Wendell PL, Fothergill LA, Perkins RE, Conroy SC, Dobson MJ, Tuite MF, et al: Sequence And Structure Of Yeast Phosphoglycerate Kinase. EMBO J 1982, 1:1635-1640.

41. Von Zabern I, Wittman-Liebold B, Untucht-Grau R, Schirmer R, Pai E: Primary and tertiary structure of the principal human Adenylate Kinase. Eur J Biochem 1976, 68:281-290.

42. Purintrapiban J, Wang M, Forsberg NE: Identification of glycogen phosphorylase and creatine kinase as calpain substrates in skeletal muscle. Int J Biochem Cell Biol 2001, 33:531-540.

43. Jia X, Hollung K, Therkildsen M, Hildrum Kl, Bendixen E: Proteome analysis of early post mortem changes in two bovine muscle types: $m$. longissimus dorsi and $m$. semitendinosis. Proteomics 2006, 6:936-944.

44. Almgren CM, Olson LE: Moderate hypoxia increases heat shock protein 90 expression in excised rat aorta. J Vasc Res 1999, 36:363-371.

45. Pulford DJ, Fraga Vazquez S, Frost DF, Fraser-Smith E, Dobbie P, Rosenvold $\mathrm{K}$ : The intracellular distribution of small heat shock proteins in post mortem beef is determined by ultimate pH. Meat Sci 2008, 79:623-630

46. Beere HM: 'The stress of dying': the role of heat shock proteins in the regulation of apoptosis. J Cell Sci 2004, 117:2641-2651.

47. Morzel M, Terlouw C, Chambon C, Micol D, Picard B: Muscle proteome and meat eating qualities of longissimus thoracis of "Blonde d'Aquitaine" young bulls: a central role of HSP27 isoforms. Meat Sci 2008, 78(3):297-304.

48. Kwasiborski A, Sayd T, Chambon C, Santé-Lhoutellier V, Rocha D, Terlouw C: Pig longissimus lumborum proteome: Part II: relationships between protein content and meat quality. Meat Sci 2008, 80:982-996.

49. Jia X, Ekman M, Grove H, Frgestad EM, Aass L, Hildrum Kl, Hollung K: Proteome changes in bovine longissimus thoracis muscle during the early post mortem storage period. J Proteome Res 2007, 6:2720-2731.

50. Bitar KN: HSP27 phosphorylation and interaction with actin-myosin in smooth muscle contraction. Am J Physiol Gastrointest Liver Physiol 2002, 282:G894-G903.

51. González B, Hernando R, Manso R: Stress proteins of $70 \mathrm{kDa}$ in chronically exercised skeletal muscle. Pflugers Arch 2000, 440:42-49.

52. Hamill RM, Marcos B, Rai D, Mullen A: Omics technologies for meat quality management. In Omics Technologies: Tools for Food Science. Edited by Benkeblia N. UK: Taylor and Francis Group Publishing; 2011:249-282.

53. Wood ZA, Schröder E, Robin Harris J, Poole LB: Structure, mechanism and regulation of peroxiredoxins. Trends Biochem Sci 2003, 28:32-40.

54. Moon JC, Hah Y-S, Kim WY, Jung BG, Jang HH, Lee JR, Kim SY, Lee YM, Jeon MG, Kim CW, et al: Oxidative stress-dependent structural and functional switching of a human 2-Cys peroxiredoxin isotype II that enhances HeLa cell resistance to $\mathrm{H} 2 \mathrm{O} 2$-induced cell death. J Biol Chem 2005, 280:28775-28784.

55. Manevich $Y$, Fisher AB: Peroxiredoxin 6, a 1-Cys peroxiredoxin, functions in antioxidant defense and lung phospholipid metabolism. Free Radic Biol Med 2005, 38:1422-1432.
56. Jia X, Veiseth-Kent E, Grove H, Kuziora P, Aass L, Hildrum Kl, Hollung K: Peroxiredoxin-6-A potential protein marker for meat tenderness in bovine longissimus thoracis muscle. J Anim Sci 2009, 87:2391-2399.

57. Adegoke OAJ, Bedard N, Roest HP, Wing SS: Ubiquitin-conjugating enzyme E214k/HR6B is dispensable for increased protein catabolism in muscle of fasted mice. Am J Physiol Endocrinol Metab 2002, 283:E482-E489.

58. Ramagli Louis S, Rodriguez LV: Quantitation of microgram amounts of protein in two-dimensional polyacrylamide gel electrophoresis sample buffer. Electrophoresis 1985, 6:559-563. 559-563.

59. Bouton PE, Harris PV, Shorthose WR: Effect of ultimate pH upon the water holding capacity and tenderness of mutton. J Food Sci 1971, 36:435-439.

60. Byrne JC, Downes MR, Donoghue N, Keane C, Neill A, Fan Y, Fitzpatrick JM, Dunn MJ, Watson RWG: 2D-DIGE as a strategy to identify serum markers for the progression of prostate cancer. J Proteome Res 2008, 8(2):942-957.

61. Guldberg Klenø T, Rønnedal Leonardsen L, Ørsted Kjeldal H, Møller Laursen S, Nørregaard Jensen O, Baunsgaard D: Mechanisms of hydrazine toxicity in rat liver investigated by proteomics and multivariate data analysis. Proteomics 2004, 4:868-880

62. Karp NA, Griffin JL, Lilley KS: Application of partial least squares discriminant analysis to two dimensional difference gel studies in expression proteomics. Proteomics 2005, 5:81-90.

doi:10.1186/1477-5956-11-9

Cite this article as: Di Luca et al:: Monitoring post mortem changes in porcine muscle through 2-D DIGE proteome analysis of Longissimus muscle exudate. Proteome Science 2013 11:9.

\section{Submit your next manuscript to BioMed Central and take full advantage of:}

- Convenient online submission

- Thorough peer review

- No space constraints or color figure charges

- Immediate publication on acceptance

- Inclusion in PubMed, CAS, Scopus and Google Scholar

- Research which is freely available for redistribution 